University of Nebraska - Lincoln

DigitalCommons@University of Nebraska - Lincoln

Faculty Publications: Department of Teaching, Department of Teaching, Learning and Teacher Learning and Teacher Education

Education

2011

\title{
The Role of Preservice Teachers' Meaning Perspectives and Schemes in a Study Abroad Experience
}

\author{
Stephanie Wessels \\ University of Nebraska-Lincoln, swessels2@unl.edu \\ Melissa Holmes \\ Kansas State University, melissa@k-state.edu \\ Socorro Herrera, \\ Kansas State University, sococo@k-state.edu
}

Follow this and additional works at: https://digitalcommons.unl.edu/teachlearnfacpub

\footnotetext{
Wessels, Stephanie; Holmes, Melissa; and Herrera,, Socorro, "The Role of Preservice Teachers' Meaning Perspectives and Schemes in a Study Abroad Experience" (2011). Faculty Publications: Department of Teaching, Learning and Teacher Education. 144.

https://digitalcommons.unl.edu/teachlearnfacpub/144

This Article is brought to you for free and open access by the Department of Teaching, Learning and Teacher Education at DigitalCommons@University of Nebraska - Lincoln. It has been accepted for inclusion in Faculty Publications: Department of Teaching, Learning and Teacher Education by an authorized administrator of DigitalCommons@University of Nebraska - Lincoln.
} 


\title{
Multicultural Learning and Teaching
}

Volume 6, Issue 2

2011

Article 5

\section{The Role of Preservice Teachers' Meaning Perspectives and Schemes in a Study Abroad Experience}

\author{
Stephanie Wessels, University of Nebraska-Lincoln \\ Melissa Holmes, Kansas State University \\ Socorro Herrera, Kansas State University
}

\section{Recommended Citation:}

Wessels, Stephanie; Holmes, Melissa; and Herrera, Socorro (2011) "The Role of Preservice Teachers' Meaning Perspectives and Schemes in a Study Abroad Experience," Multicultural Learning and Teaching: Vol. 6: Iss. 2, Article 5.

DOI: $10.2202 / 2161-2412.1089$ 


\title{
The Role of Preservice Teachers' Meaning Perspectives and Schemes in a Study Abroad Experience
}

\author{
Stephanie Wessels, Melissa Holmes, and Socorro Herrera
}

\begin{abstract}
This microethnographic case study focuses on patterns of interpretation and decision making of undergraduate preservice teachers as they participated in observations, co-teaching, and teaching in elementary schools in northern Mexico. At the core, this study explores the deeply embedded assumptions preservice teachers may bring to new cross-cultural interactions. Drawing from participant documents, surveys, and interviews, the study seeks to investigate the meaning perspectives and schemes (Mezirow, 1991) that study abroad participants used to make sense of their experiences. Also explored are ways the study abroad experience may have helped to alter or solidify meaning perspectives. Finally, recommendations based on lessons learned are provided for designing study abroad experiences that prompt preservice teachers to view and use cultural differences as assets in classroom practice.
\end{abstract}

KEYWORDS: preservice teachers, study abroad, meaning perspectives 
Wessels et al.: Meaning Perspectives in a Study Abroad Experience

\section{Introduction}

The benefits of international experiences in relation to the field of education are well documented. Many authors and researchers (e.g., Blair, 2002; Cushner, 2007; Mahan \& Stachowski, 1994; Merryfield, 2000; Quezada, 2004; Willard-Holt, 2001) discuss the positive effects that international experiences can have on an individual, including increased self-confidence, adaptability, intercultural sensitivity, open-mindedness, and global awareness. Study abroad experiences also have the potential to impact beliefs and values (Dooley et al., 2008). Cushner (2007) suggests that such experiences can enhance preservice teachers' understanding of culture and language learning processes, resulting especially in empathy that then can be applied to domestic diversity when they have their own classrooms.

With the increasing diversity in U.S. classrooms, the need for teachers who are culturally sensitive is critical (Marx \& Moss, 2011). A study of preservice teachers by Larke (1990) found that, although most preservice teachers realized their future students would be from diverse backgrounds, only one-fifth of the respondents admitted to a preference to work with students of different cultures. Nearly half (43.1\%) indicated that they would prefer to work with students who share their own cultural background, thus supporting the need for increased preservice teacher training on cross-cultural awareness. Stachowski et al. (2003) studied the effects of cultural exposure on pre-service students, and found the greatest impact on teachers' perspectives in the classroom. Teachers not only reported an increased interest in other cultures, but also in integrating crosscultural teaching experiences into their U.S. classrooms. Such potential benefits of international experiences prompt many university teacher education programs in the United States to incorporate study abroad opportunities for their preservice teachers.

International experiences designed specifically for elementary and secondary education majors include study abroad trips, which Quezada (2004) refers to as a "tourist approach," and student teaching abroad experiences that involve immersion of preservice teachers in other countries. Although long-term experiences may have a greater effect on the interpersonal dimension due to increased exposure to the receiving country, culture, and community as well as fewer sending country support structures (Cushner, 2007), many universities that are trying to make international experiences affordable and available to all interested students choose to develop short-term study abroad trips.

Trip duration is just one of a multitude of personal and contextual factors that can affect an individual's international experience as well as his or her perspectives about the host country and culture. Personal factors frequently stem from one's socialization and include openness to diversity and readiness for cross- 
cultural experiences as well as proficiency in the host country language (Marx \& Moss, 2011; McKay \& Montgomery, 1995; Quezada, 2004; Stachowski \& Visconti, 1997). Contextual factors might include program preparation and expectations (McKay \& Montgomery, 1995; Stachowski \& Visconti, 1997); placements with host families (Quezada, 2004); readiness of host schools and teachers to receive preservice teachers (Yang, 2011); and strategies employed by program staff to help participants navigate cross-cultural challenges (Marx \& Moss, 2011). The role that these factors play in preservice teachers' international experiences as well as their influence on trip outcomes is unique to each international experience and to each participant in the group.

This paper explores the role of socialization in preservice teacher participants' interpretations of classroom experiences during a study abroad trip to northern Mexico. Cushner et al. (2006) define socialization as a process by which members learn group norms; such "patterns may include the acquisition of a particular language, knowledge of social roles and role behavior, and particular understandings of all aspects of the physical and social environment and normative behaviors toward it" (p. 78). Beliefs and attitudes such as those related to educational issues are formed to some degree by an individual's primary socialization, but to a much greater degree by one's secondary socialization. Primary socialization relates to the influences of one's childhood caregivers and home life on his or her perspectives; secondary socialization, on the other hand, is largely associated with the influence of school (Cushner et al., 2006).

The beliefs about education that one has developed through socialization in a particular culture then may be used to view and make judgments about pedagogy situated in another culture. As Herrera and Murry (2005) note, "ambiguity, assumptions, miscommunications, attributions, and tensions are inevitable" in cross-cultural interactions if an educator's prior socialization has involved little experience with cultural and linguistic diversity (p. 130). In this case study, the researchers explored the influence of socialization on preservice teachers' beliefs about educational practices and the participants' resulting interpretations of observations made in Mexican pedagogical settings. Of interest were participants' perspectives on educational issues such as the following:

- What should teaching look like? What is the role of the teacher?

- What should learning look like? What types of student interaction should be utilized?

- What should classrooms look like? What kinds of resources are needed for teaching and learning?

- What should classroom management look like? What behavior management techniques should be employed? 
Wessels et al.: Meaning Perspectives in a Study Abroad Experience

\section{Theoretical Framework}

The theoretical underpinnings for this study related to Mezirow's transformative learning theory, in which "learning is understood as the process of using a prior interpretation to construe a new or revised interpretation of the meaning of one's experience in order to guide future action (Mezirow, 1996, p. 162). Taylor (1997) defines the purpose of transformative learning as an attempt "to explain how our expectations, framed within cultural assumptions and presuppositions, directly influence the meaning we derive from our experiences" (p. 14). Cranston (1994) views transformative learning as being concerned with "how learners construe, validate, and reformulate the meaning of their experience" (p. 22).

According to Mezirow (1991), meaning structures are composed of meaning perspectives and meaning schemes. A meaning perspective is defined as the "structure of assumptions within which one's past experience assimilates and transforms new experience" (Mezirow, 1991, p. 42). In other words, a meaning perspective consists of a set of expectations that serve as an orienting frame of reference or worldview. These meaning perspective expectations become a tacit belief system for each individual that he or she applies to make sense of new experience. Mezirow (1991) writes that meaning perspectives "mirror the way our culture and those individuals responsible for our socialization happen to have defined various situations" (p. 131). A meaning perspective also influences what one attends to and remembers about an experience. Because they have been acquired throughout a person's life, meaning perspectives become part of an individual's makeup and are difficult to change (Taylor, 1997).

Mezirow elaborates on three types of meaning perspectives-epistemic, psychological, and sociolinguistic - that guide an individual's interpretations and evaluations of experience. Epistemic meaning perspectives relate to how an individual knows what he or she knows and the resultant uses of such knowledge. Among others, Mezirow (1991, p. 43) lists the following as factors that contribute to and shape such perspectives: (a) developmental stage perspectives, (b) cognitive/learning/intelligence styles, (c) sensory learning preferences, (d) scope of awareness, (e) external/internal evaluation criteria, (f) global/detail focus, (g) concrete/abstract thinking, and (h) reflectivity.

Psychological meaning perspectives relate to one's feelings and the sense of how one desires to be as an adult. Mezirow (1991, p. 43) mentions the following as factors that may shape an individual's psychological meaning perspectives: (a) self-concept, (b) locus of control, (c) tolerance of ambiguity, (d) lost functions - childhood prohibitions enforced by anxiety in adulthood, (e) inhibitions, (f) psychological defense mechanisms, (g) neurotic needs, and (h) approach/avoidance. 
Given this study's focus on preservice teachers' educational assumptions and beliefs in the context of a cross-cultural experience, the third type of meaning perspective, sociolinguistic, is of particular relevance. Sociolinguistic meaning perspectives relate to influences of society and language on an individual's perceptions and understanding of reality. Among factors that shape and influence one's sociolinguistic meaning perspectives, Mezirow (1991, p. 43) notes the following: (a) social norms/roles, (b) cultural/language codes, (c) language/truth games, (d) common sense as cultural system, (e) secondary socialization, (f) ethnocentrism, (g) prototypes/scripts, and (h) philosophies/theories. These factors also can limit and distort the sociolinguistic meaning perspectives that one uses to understand experiences.

Each meaning perspective, Mezirow further explains, comprises several meaning schemes. A meaning scheme can be defined as "the particular knowledge, beliefs, value judgments, and feelings that become articulated in an interpretation" (1991, p. 44). Meaning schemes are smaller components that reflect the overarching meaning perspective and that serve to guide one's actions in a given situation. Meaning schemes can involve, for example, social roles and relationships, such as teacher-student. In this study, the researchers sought to identify the preservice teachers' overarching meaning perspective and component meaning schemes that guided their interpretations.

Because meaning perspectives affect individual interpretations, it is important to disclose the backgrounds of the researchers involved in this study. Wessels is a White, monolingual-English speaking female educator who served as the facilitating faculty member on this study abroad trip. With a background in training educators to work with culturally and linguistically diverse students, she was also the primary instructor for the ESL endorsement courses taught over the three-week period in Mexico. Holmes is a White female educator, born and raised in the Midwest, who has a basic understanding of Spanish and has spent time in Central America. She was involved in this research as a peer debriefer who played the role of devil's advocate by asking probing questions pertaining to researcher biases, meanings, and foundations for interpretations (Lincoln \& Guba, 1985). Herrera is a Mexican immigrant whose life and livelihood have been influenced by the dynamics of what it means to be an English language learner in the United States. She directs the particular center within the College of Education that spearheads the Midwestern University study abroad trips to Mexico. She spent a week in Mexico observing the participants' interactions and networking with school administrators. 
Wessels et al.: Meaning Perspectives in a Study Abroad Experience

\section{Research Questions}

Institutions of higher education often tout study abroad programs as the best means of developing preservice teachers' cross-cultural awareness and global worldviews. However, little has been written regarding how study abroad experiences may be influenced by the meaning perspectives that preservice teachers carry with them from their own socialization and how such perspectives may impact participants' interpretation of pedagogy and learning in a new context. Therefore, this study sought to address the following questions:

1. In what ways do preservice teachers' meaning perspectives regarding K-12 educational practices and the teaching and learning processes in Mexican classrooms get formed as a result of a study abroad experience?

2. How do preservice teachers' prior socialization contribute to these meaning perspectives?

\section{Context of the Study}

To increase the contact that preservice teachers have with diversity and to promote their development of cross-cultural competencies, Midwestern University, a predominantly white university, initiated a three-week study abroad experience in the summer of 2008 to an urban city in northern Mexico. This was one of 8 similar study abroad experiences that took place between 2005 and 2011, and it was the third trip to Mexico. The primary focus of this study abroad experience, as conceptualized by the university, was to educate preservice teachers about an educational system that differs from the U.S. public school system. Mexico is the leading country of origin for the fastest growing culturally and linguistically diverse student population in U.S. public school systems; $72 \%$ of students who speak a language other than English at home speak Spanish as their native language (August \& Shanahan, 2006). Therefore, Mexico was a natural fit for being selected as the receiving country.

The majority of preservice teachers' time in Mexico was devoted to observation and involvement in elementary school classrooms as well as completion of Midwestern University coursework (up to six credit hours). The courses taught were part of a larger sequence of courses (15 credit hours total) designed to help educators attain an English as a Second Language (ESL) endorsement. While the participants were in Mexico, they were placed in pairs with host families to promote a broader understanding of the culture and home life of a Mexican family. In addition to the host family experience, participants 
were provided optional weekend excursions to local cultural sites to extend their cultural competence while in Mexico.

Participants were placed in one of two public elementary schools, one of which had served as a successful host site for previous study abroad trips. According to school administrators, these schools were representative of schooling in an urban city of northern Mexico. Each of the schools served approximately 400 students in grades 1-6 with students from mostly middle to lower socioeconomic backgrounds, as defined by school administration. Both schools were Spanish-only settings with no dual language (English and Spanish) instruction taking place throughout the instructional day. Participants in the study were in the elementary classrooms five days a week from 8:00 a.m. to 1:00 p.m., the timeframe of a school day in Mexico.

Prior to their departure from the United States, participants received the university's traditional Office of International Program (OIP) training on expectations of studying in another country. The main purpose of this OIP training was to provide support before departure and enhance the students' ability to make successful cultural adjustments. However, this OIP training consisted largely of information pertaining to oversees travel in European countries and did not address the concept of culture and how it influences one's ability to understand and function in a new and unfamiliar environment. In addition, many of the questions posed by this group of preservice teachers related to vaccines, currency exchange, border crossing, and other issues specific to travel in Mexico that OIP staff could not answer because they were unfamiliar with the issues. Center staff conducted two additional orientations for participants to address these and other educational and logistical issues.

\section{Participants}

This research study involved 15 preservice teachers (one male and fourteen females) taking part in the university-sponsored study abroad program to Mexico. Of these undergraduate students, 3 were Mexican-American, 10 were Caucasian, and 2 were African-American. Three were Spanish-dominant bilingual, 6 were English-dominant bilingual, and 6 had only limited Spanish or were completely monolingual-English speakers. One of the participants was born outside of the United States; the rest of the participants were born and raised in the Southwest and Midwest regions of the United States. Eight of the participants were seniors in college, 6 were juniors, and 1 was a sophomore. Participant ages ranged from 20 to 50 years. All participants were enrolled in an education program as well as an ESL licensure-track program for K-12 teaching in public school settings. 
Wessels et al.: Meaning Perspectives in a Study Abroad Experience

\section{Methodology}

This research was undertaken as a qualitative, microethnoographic case study of the meaning perspectives study abroad students had regarding the teaching and learning practices of teachers and students in Mexican schools. The microethnographic methodology (Denzin, 1997; Miles \& Huberman, 1994) chosen as the basis for data collection and analysis was appropriate given that the researchers sought to describe and interpret data arising from discovery, insights, and analysis (Creswell, 2007). The researchers collected data from participants throughout the study abroad experience. Additional follow-up data collection took place approximately 10 months later.

Data for this case study were collected using (a) coursework documents, including artifacts and written reflections, (b) open-ended follow-up surveys (see appendix A), and (c) semi-structured, individual, follow-up interviews that were recorded and later transcribed for detailed analysis. The semi-structured interviews involved some common questions regarding participants' experiences and other questions that openly explored their perceptions regarding their study abroad experience. This allowed the students to direct the interviews toward areas they felt were most meaningful. Students were assured that all information would remain confidential.

Analyses of this study were guided by general strategies including reading the data for a sense of the whole, documenting reflections, coding the data, and developing themes and patterns from the data and codes. This analytic process was iterative and simultaneous with data collection. Emerging themes were grounded in participants' documents, surveys, and information gleaned from the recorded and transcribed semi-structured interviews (Glaser \& Strauss, 1967; Lancy, 1993). Interview transcripts were analyzed using qualitative coding procedures, as outlined by Strauss and Corbin (1990), along with other organizational tools suggested by Miles and Huberman (1994).

The researchers began with opening coding methodology by placing conceptual labels on selected segments of the participants' interview transcripts, documents, and surveys to represent the preliminary themes emerging from the data (Strauss \& Corbin, 1990). However, once the data began to yield deeper information beyond conceptual labels, the researchers started to look at the coding more analytically for categories, or themes of information (Morse \& Richards, 2007) that allowed for comparison. Once the initial analytical coding was complete, the broader categories resulted in one overarching meaning perspective and three meaning-scheme themes ("axial coding") (Strauss \& Corbin, 1998). As the analysis progressed, the researchers used the analytic strategy of the constantcomparative approach to build and confirm emerging theory (Lincoln \& Guba, 1985). Through this process of examining the data, the emergent categories were 
gradually modified to best represent the data. Thick, rich descriptions were used to identify the participants' meaning perspectives and their role in developing cross-cultural understanding or assumptions (Lincoln \& Guba, 1985).

Instead of issues of reliability and internal and external validity, this qualitative research study used validation strategies to ensure the credibility and trustworthiness of the findings. Several validation strategies were used, including triangulating findings across multiple sources of data, having multiple coders of the data with frequent discussions of differences found in coding, and sharing initial findings with a participant as a form of member checking (Creswell \& Miller, 2000). The data triangulation of the participants' documents, surveys, and semi-structured interviews provided a "fuller, richer, more trustworthy picture" (Rhodes \& Shanklan, 1993, p. 21).

\section{Findings and Discussion}

The researchers' data analysis revealed that Mezirow's sociolinguistic meaning perspective was the most informative of the three meaning perspectives with regard to understanding how participants interpreted their experiences in Mexican pedagogical settings. Despite enthusiasm among many participants for select educational processes and practices they witnessed (e.g., use of technology in classrooms; independence of students as thinkers and learners), the overarching sociolinguistic meaning perspective of participants that emerged from data was: U.S. educational practices are effective-Mexican children get shortchanged. This meaning perspective was evident in participants' voice, as demonstrated by the following quote from a semi-structured interview.

I had a feeling of stress and sadness the whole time. I felt that the students in my classroom could do more than what they were asked to do. I felt that the students were getting short changed by the teacher and the system.

As illustrated by this quote, participants believed that the education of Mexican children was hindered at the classroom level as well as at the level of the larger school system in comparison to their own schooling experiences. In responding to the survey, one participant further addressed perceived inadequacies of the Mexican educational system by pointing out the apparent lack of standards to guide curriculum implementation.

In the U.S., we aim for very high standards of performance. The teacher I observed in Mexico showed no apparent standards in her classroom. 
According to this participant's ethnocentric logic, it follows that without explicit use of and reference to such academic standards, teachers are not appropriately (if at all) using standards to guide their instruction and, therefore, are not providing students with an appropriate, challenging academic curriculum. This viewpoint exemplifies the tendency of participants to use their own prior socialization as a benchmark for judging the appropriateness and effectiveness of educational practices rather than reflecting on what might be learned from the educational practices of another culture and setting.

\section{Meaning Schemes}

To illustrate the sociolinguistic meaning perspective, three meaning-schemes themes emerged from data analysis. These meaning schemes related to participants' beliefs about structure, teacher control, and professionalism in the Mexican education system. Each meaning-scheme theme is discussed below.

\section{Meaning Scheme \#1: Structure Signals High Expectations for Student Learning}

Participants identified a lack of structure as one of the key differences between U.S. school settings and Mexican school settings. One interviewee expressed this meaning scheme in the following way.

Classes here are so different than the U.S. There isn't really any structure within the school as a whole.

Other participants addressed structure at the classroom level. In responding to the survey, another student shared the following perspective.

Classes seem more relaxed and less structured. This could be a positive aspect because too much structure can bring about high stress levels. However, this could be a negative aspect in regards to too much freedom and how much material the students are actually learning.

This preservice teacher attempted to provide a balanced view of the role of structure in the classroom. For example, the participant noted that "too much structure" can raise students' anxiety. However, the subtext of this excerpt is that the Mexican classroom exemplifies the other end of the spectrum - one of "too much freedom," where the amount of material being learned by students is in question. The general sense of the data revealed that participants know there are various school systems and methods of instruction used around the world and that 
discrepancies between those exemplified in other countries and those exemplified in the United States should be viewed as "different," not necessarily as "inferior." Yet, participants' prior socialization left its mark in many ways on the final interpretations they made about their observations and experiences.

\section{Meaning Scheme \#2: Teacher Control Is a Requisite for Student Learning}

Participants overwhelmingly decried a lack of teacher control in the classrooms they observed. Their reflections revealed a tendency to view student behavior as a measure of student learning. One interviewee simply listed the following regarding classroom observations.

Kids constantly getting out of their seats...students not disciplined when they misbehave.

Like this student, participants often made assumptions about the conduct observed in Mexican classrooms, relying on their value-laden notions about what classroom behavior conducive to learning should look like. A document from another participant revealed the following perspective in relation to student behavior.

In the classroom, a lot of the teachers just let the kids do whatever they want whenever they want.

Other participants were more emotional in their responses. One such participant discussed the teacher's classroom management in the follow-up interview.

The teacher never moved from her seat. She would sit there and yell out directions to the assignments, which seemed optional. I would say that 5$10 \%$ of the students would be doing the assignments and the rest was just mass chaos. No wonder the percentage is so low of students going on to school.

This participant, like many others, views Mexican children as victims of an educational environment that provides minimal teacher involvement and guidance. In the mind of this preservice teacher, insufficient teacher control yields "mass chaos" and leaves students' learning to chance. 
Wessels et al.: Meaning Perspectives in a Study Abroad Experience

\section{Meaning Scheme \#3: Professionalism Is Fundamental to Teaching}

Numerous participants criticized the professionalism of the Mexican teachers they observed. Some students highlighted the lack of student supervision. One student relayed the following scenario.

I would go to class every morning, and at least once a day the teacher would leave without saying anything for approximately thirty-minute intervals. At first I thought maybe she thought I was watching over her classroom, so maybe it was the language barrier that distanced my judgment. However, after she returned from her "break" one day, the children were in utter chaos throwing sunflower seeds around the room from an art project, pushing and shoving one another, and yelling at the top of their lungs as if it were a competition. As she entered, the children continued on and she said nothing; therefore, she was not concerned if I was there to witness and keep order or not.

A lack of professionalism was also noted in relation to teachers' use of cell phones. One preservice teacher shared the following.

The unrestricted use of a cell phone while class is being conducted was apparent while I was observing. The teacher would answer her phone and dawdle with the buttons several times a day. Although her conservations would not last for more than three minutes, it is not a constructive use of time in the eyes of a United States soon-to-be educator.

Finally, the way Mexican teachers dressed was objectionable to many participants. One participant described the dress code in this way.

First of all, the teachers dress like they are going to a club...they wear spaghetti straps, tight jeans, revealing clothes, high heel shoes...

Taken together, these kinds of observational comments illustrate (a) the value participants place on norms of professionalism in U.S. educational settings and (b) participants' expectations of similar norms in cross-cultural settings. The participants projected onto the Mexican educators their own beliefs about what constitutes a high quality teacher. 


\section{Reflective Learning}

A meaning perspective is such an integrated part of our overall belief system that it is no wonder that "the most significant transformations in learning are transformations of meaning perspectives" (Mezirow, 1991, p. 38). Mezirow points out that it is easier to change a meaning scheme than it is to change a meaning perspective. The participants' sociolinguistic meaning perspective regarding U.S. and Mexican educational practices would likely be difficult to transform unless the component meaning schemes were first addressed.

Throughout their time in Mexico, participants were asked to reflect on their learning. They were also provided with additional opportunities to reflect on their study abroad experience via follow-up surveys and interviews. Yet, as Mezirow notes, "Reflective learning can be either confirmative or transformative" (p. 111). Meaning schemes can be changed by becoming "reinforced, elaborated, created, negated, confirmed, or identified as problems (problematized) and transformed" (p. 111). For many participants, their shared experiences, observations, and interpretations served to merely confirm and reinforce the previously discussed meaning schemes.

Other participants took initial steps toward problematizing the meaning schemes they were using to make sense of their experiences. According to Mezirow, all transformation of meaning perspectives and meaning schemes begins with a willingness to test the validity of (i.e., reflect on) one's assumptions. One becomes involved in critical reflection by going a step farther to analyze of the premise behind such assumptions. One participant shared the following transformative change in meaning scheme.

The first week I felt the room had little control and little discipline. However the second week, I realized that the students were learning the information she was teaching. They were learning in their own way. I enjoyed watching their classroom environment and how laid back it was. I felt that I was there to learn about the culture. She allowed me into her classroom and it was not my place to start changing the way she ran her classroom.

This participant became open to acknowledging that higher degrees of teacher control may not be essential to student learning - that there may be more than one way to get the same result. However, by stating, "it was not my place to start changing the way she ran her classroom," this preservice teacher signals her adherence to the original meaning perspective, which held that U.S. educational practices in general are more effective. Although the larger meaning perspective had not changed, this reflection illustrates that the participant was willing to test 
Wessels et al.: Meaning Perspectives in a Study Abroad Experience

the validity of assumptions related to the second meaning scheme (i.e., Teacher control is a requisite for student learning).

\section{Contributing Effects of Participants' Socialization}

For many participants, this study abroad experience was one of their first steps in gaining a more global understanding of the world and in developing empathy for culturally and linguistically diverse students who face linguistic and cross-cultural challenges. Eight of the participants had grown up within a 120 -mile radius of Midwestern University, and two other students had lived their entire lives in the city in which the university is located. For nine participants, this was their first experience outside the United States. The majority (80\%) of participants were from middle or high socioeconomic backgrounds. The overall reactions of the 15 participants toward this study abroad experience serve to divide this group into two subgroups.

The first subgroup of eight participants struggled with the daily life and dynamics of living in a culture different from their own. Members of this group shared several similar characteristics. Six of the eight group members had not been outside the country prior to this study abroad program. Their understandings of international travel had been gained through media such as television and magazines. The participants struggled with daily dynamics related to (a) variety of foods, (b) limited use of resources (air conditioning, water, paper products), (c) time orientation of cultural setting, (d) lack of Spanish language skills and other forms of communication (e.g., telephone, email), and (e) lack of independence due to transportation constraints.

In this subgroup, two of the group members spoke limited Spanish; however, the other six members of this group had no Spanish language skills. Although some participants attempted to speak the language, the majority of this group became dependent on the bilingual trip participants or bilingual students in the classroom. This subgroup of preservice teachers did not readily participate in the classroom instruction and activities. Six participants spent the largest portion of their time merely observing from the outskirts of the classroom, which caused them to feel helpless and not very useful. The participants then blamed their lack of involvement on ineffective communication between the classroom teacher and themselves. The comments of the following participant illustrate this scenario.

I felt like I was contributing nothing to the classroom because I couldn't help the students when they asked me. If I could go back and change this experience I would have tried to ask the teacher for a grading key to help grade with and if I couldn't communicate this point I would have asked one of the bilingual people on the trip to help me. 
Beyond expressing that they did not find being in the classroom very beneficial, five of these participants also suggested that their time could have been better spent exploring other school systems in Mexico. Not surprisingly, this subgroup of participants demonstrated less transformative thinking with regard to the meaning perspective and meaning schemes previously described.

The second subgroup of seven participants seemed to adapt to the changes in culture and language. These participants were more open to the study abroad experience and more flexible with regard to daily challenges and dynamics throughout their time in Mexico. The following comments exemplify the type of perspective this subgroup shared.

Some of the participants seemed to have their minds made up to be negative and a downer for the rest of the group. This was unfortunate for those of us who enjoy learning and taking advantage of any opportunity that is presented to us. Every experience can produce a positive outcome, and for me this outcome was to continue my knowledge of different types of people and how I could help individuals (like some of those in our group) adjust to being successful in my future classroom.

This group of participants had some previous international travel experience and six spoke Spanish with varying levels of proficiency; only one of the participants was a monolingual-English speaker. In the classrooms, these preservice teachers did not hesitate to provide students with assistance in their assignments. Without being directed by the teacher, the participants took the initiative to circulate around the room and provide the children with individual attention and support. They tried to apply the knowledge and skills they had gained through coursework in their new classroom settings. One of the participants from this subgroup shared the following comment in the semistructured interview.

There was growth of my educational knowledge through the application that took place. I have spent the last two semesters reading about the use of pictures, gestures, vocabulary scaffolding, hands-on activities, informal assessment, etc. Having the opportunity to work with the students and use these methods and assessment strategies really enforced their instructional benefits. I was able to see the kids understanding and enjoying. They "got it" through the strategies I was using even though we spoke next to none of the same language. I was able to grow in my belief and understanding of the ESL methods I have gained through my coursework. I now have a better idea of what will work for CLD students in my future classroom. 
Wessels et al.: Meaning Perspectives in a Study Abroad Experience

This experience reinforced what I knew and allowed me to grow in my confidence in the methods and my own ability.

This participant was able to draw upon knowledge gained from previous courses at the university to work effectively with students in another school setting. As such, her experiences during the study abroad trip reinforced her understanding of theory and its application in practice. She worked in collaboration with her classroom teacher to teach three lessons to students while in Mexico.

\section{Educational Implications}

This study has implications for teacher pedagogy with Mexican American and other students of diverse backgrounds in K-12 classrooms as well as for teacher preparation programs in institutions of higher education. When preservice teachers graduate and enter the field with meaning perspectives and meaning schemes such as those previously discussed, they bring to the classroom a deficit perspective (Valencia, 1997) on Mexican educational practices. When this is the case, teachers are less likely to value the prior academic learning of Mexican immigrant students and to seek ways of uncovering their background knowledge related to the content-area concepts. Without reflective and transformative learning, the same expectations and beliefs about education that resulted from socialization in a particular culture will continue to influence teachers' assumptions when working with students from diverse backgrounds. These assumptions can have a profound effect on how teachers interact with, teach, and guide students from diverse backgrounds to meet high academic expectations.

As humans, we all have personal histories and cultural backgrounds that shape the ways we view the world and act on and within it (Eisner, 1998). Teachers' ability to adjust the lens through which they view and interpret teaching and learning dynamics within their work requires an understanding of the importance of attending carefully to their assumptions, beliefs, and knowledge base (Major \& Brock, 2003). Their knowledge about a culture can influence their interpretations of instructional encounters with students and shape the ways they make instructional decisions in the classroom. Therefore, as Brisk et al. (2002) assert, teachers "must learn to reflect upon (test the validity of) the influence of their cultural filter upon perspectives and actions in practice with diversity" (p. 5).

A study abroad experience can go a long way in helping educators develop a more informed perspective about students whose socialization experiences do not mirror their own. The following participant comment conveys the type of insights that preservice teachers can glean from such opportunities. 
Some of the individuals within our group had a very difficult time adjusting to life in a foreign country, and their reactions to situations would probably be similar to that of a middle school or high school-aged student. Watching how those individuals intermingled and related to their cooperating teachers and their host families was a great indicator of how some ESL students might react in the same situation. I am now a firm believer that you need to place yourself in their shoes if you truly want to understand your students and how they feel. Once you truly understand how they feel then you will be able to effectively teach those students.

The empathy this participant now has for students adjusting to a new country, culture, and language is likely to positively influence future relationships with students, classroom decisions, and instructional practices.

Implications of this study for teacher preparation programs relate to the design of study abroad experiences for preservice teachers. Because many undergraduates have relatively little experience with cultural and linguistic diversity, considerable attention must be paid to designing experiences that promote the kind of reflective learning that, as necessary, leads to transformation of meaning perspectives and related meaning schemes. Essential to this process is faculty awareness of each participant's biography (i.e., primary and secondary socialization).

Based on lessons learned from this study, the following are recommendations for designing international experiences that prompt preservice teachers to view and use cultural and linguistic differences as assets in classroom practice.

1. Provide potential participants with a thorough introduction to the host culture and community prior to departure. Encourage preservice teachers to share assumptions they may have about what educational practices will look like in the host country. Use selected readings on topics such as culturally relevant pedagogy, socialization, and schooling in the U.S. compared to schooling in other countries (both positives and negatives) to begin reflective discussions.

2. Ensure that upon arrival in the host community, participants have opportunities to discuss with school administrators and host teachers the educational philosophy of the school as well as the teachers' philosophies on pedagogy. If the native language of the host country is not English, provide participants with guidance on how to navigate communication challenges (e.g., use nonverbal communication such as gestures and pictures, seek out the help of bilingual peers). To aid communication and understanding between the preservice teachers and their host teachers, 
Wessels et al.: Meaning Perspectives in a Study Abroad Experience

supply participants with a packet that provides translations for basic educational phrases, along with a pronunciation key. Ideally, the facilitating faculty member should be proficient in the language of the host country.

3. Collaborate with host schools/teachers to design classroom experiences that, to the greatest extent possible, encourage preservice teachers' active participation as well as teaching/co-teaching of the students.

4. Following each day's classroom observations and teaching, provide participants with opportunities to debrief and reflect on the day's events. Prompt participants to critically reflect on ways their own socialization may be influencing their interpretations of classroom observations and experiences. Challenge them to identify and then test the validity of assumptions they might have made about the students, teachers, classroom practices, and larger educational system they encountered. Have students keep a daily journal to support these reflection processes and subsequent discussion.

5. Encourage participants to identify pedagogical strategies and ideas that might enhance their future teaching, and help them develop a broader perspective on effective educational practices.

6. Ensure that upon return to their home country, participants have additional opportunities to explore lessons learned and to reflect, and especially critically reflect, upon their experience as a whole. Encourage application of learning to practicum experiences or hypothetical teaching situations.

These recommendations integrate extensive preparation prior to students' departure, daily guidance and support for participants as they negotiate the challenges and nuances of teaching and living in a different country, and opportunities after returning for continued reflection.

\section{Conclusion}

Whether long-term or short-term, international experiences provide preservice teachers with powerful opportunities to learn more about themselves and the larger world. The goal for educators is to frame and guide such experiences in ways that promote preservice undergraduates' transformation of potentially negative meaning perspectives and meaning schemes through reflective learning. The overarching meaning perspective that emerged from the voices of the 15 preservice teacher participants in this study was: U.S. educational practices are effective-Mexican children get shortchanged. This meaning perspective was 
exemplified through three meaning-scheme themes that related to structure, teacher control, and professionalism.

Throughout the course of the study, some participants began to make changes to the meaning schemes that influenced their perceptions and interpretations of observations and interactions with the students, teachers, and schools. Such transformations allowed, for example, greater openness to seeing the potential benefits of the Mexican educational system. However, the larger meaning perspective of the participants remained intact. In general, they continued to view U.S. educational practices as superior to those they witnessed in Mexico. Although this outcome may be the result of participant experiences and observations that were neither reflective of the larger Mexican educational system nor representative of the individual schools and classrooms involved in this study (and in fact often contradicted those of previous study abroad trips to the same school), it nonetheless must serve as a catalyst for continued efforts to build cross-cultural understanding among preservice teachers.

This finding also presents a note of caution to universities and faculty involved in preservice teacher preparation and a challenge to the larger field of education. Significant efforts must be made to encourage among preservice and inservice teachers the type of reflective learning that spurs critical reflection on one's socialization and its influence on assumptions made in practice. When educators are able to view immigrant students' prior academic experiences in other countries as a valuable foundation to their language and content learning in U.S. classrooms, they are more likely to delve into and make us of the assets that students bring. 
Wessels et al.: Meaning Perspectives in a Study Abroad Experience

\section{Appendix A}

\section{Participant Survey}

\section{Summer 2008 Mexico Trip}

\section{Biographical Facts}

1. Name:

2. Age at time of trip:

3. Race/ethnicity:

4. Native language:

5. Proficiency in Spanish (please choose one of the following): Non-speaker Limited proficient speaker (i.e., high school and/or some college courses) Proficient speaker

6. Other languages spoken:

7. Country of origin:

8. Hometown:

9. Elementary, middle, and high schools you attended (in your childhood):

10. Class standing at time of trip (i.e., Freshman, Sophomore, Junior, Senior):

11. Progress toward educational degree at time of trip (please choose one of the following):

Not yet admitted to the College of Education

Taking Pre-Professional Education coursework

Completed Block A or Block I

Completed Block B or Block II

12. If admitted, are you an Elementary Education or Secondary Education major?

13. Which, if any, ESL courses had you taken prior to this trip? Please mark all that apply.

ESL Methods

ESL Assessment

ESL Linguistics

ESL Curriculum Materials (Multicultural)

ESL Practicum 


\section{Classroom Events in Mexico}

Describe three events that caused you to reflect upon your perspectives on teaching practices.

1.

2.

3.

Putting Yourself in the Scene

Think of one classroom in which you spent time observing. Now put yourself back in the scene. What was the teacher doing? What were the students doing? What did you notice regarding resources? Think about what you observed, thought, and felt. Below, try to describe and recapture those observations, thoughts, and feelings.

\section{Reflections}

1. What are the most drastic differences between schooling in the United States and schooling in Mexico? Which do you consider positive differences? Which do you consider negative differences?

2. Which, if any, aspects of the Mexican teaching/learning dynamics might you bring into your future classroom practice?

3. What implications might this trip have for you if you later have a Mexican immigrant or Mexican American student in your classroom? 
Wessels et al.: Meaning Perspectives in a Study Abroad Experience

\section{References}

August, D. \& Shanahan, T. (2006). Synthesis: Instruction and professional development. In August \& Shanahan (Eds.), Developing literacy in second language learners: Report of the National Literacy Panel on language-minority children and youth (pp. 351-364). Mahwah, NJ: Erlbaum.

Blair, J. (2002). Colleges sending teacher-candidates to see the world. Education Week, 22(15), 8.

Brisk, M. E., Barnhardt, R., Herrera, S., \& Rochon, R. (2002). Educators' preparation for cultural and linguistic diversity: A call to action. Washington, DC: American Association of Colleges for Teacher Education. (ERIC Document Reproduction Service No. ED477737)

Cranton, P. (1994, November/December). Self-directed and transformative instructional development. Journal of Higher Education, 65(6), 726-744.

Creswell, J. W. (2007). Qualitative inquiry and research design: Choosing among five approaches. Thousand Oakes, CA: Sage.

Creswell. J. W., \& Miller, D. L. (2000). Determining validity in qualitative inquiry. Theory into Practice, 39, 124-130.

Cushner, K. (2007). The role of experience in the making of internationallyminded teachers. Teacher Education Quarterly, 34(1), 27-39.

Cushner, K., McClelland, A., \& Safford, P. (2006). Human diversity in education: An integrative approach (5th ed.). Boston: McGraw-Hill.

Denzin, K. (1978). The researcher act. New York: McGraw-Hill.

Dooley, K. E., Dooley, L. M., \& Carranza, G. (2008). Beliefs, barriers, and benefits of a faculty abroad experience in Mexico. Journal of International Agricultural and Extension Education, 15(3), 29-38.

Eisner, E. (1998). The enlightened eye: Qualitative inquiry and the enhancement of educational practice. Columbus, $\mathrm{OH}$ : Prentice Hall. 
Glaser, B., \& Strauss, A. (1967). The discovery of grounded theory. Chicago: Aldine.

Herrera, S., \& Murry, K. (2005). Mastering ESL and bilingual methods: Differentiated instruction for culturally and linguistically diverse (CLD) students. Boston: Allyn and Bacon.

Lancy, D. (1993). Qualitative research in education: An introduction to the major trends. New York: Longman.

Larke, P. J. (1990). Cultural diversity awareness inventory: Assessing the sensitivity of pre-service teachers. Action in Teacher Education, 12(3), 23-30.

Lincoln, Y. S., \& Guba, E. G. (1985). Naturalistic inquiry. Newbury Park, CA: Sage.

Mahan, J. M., \& Stachowski, L. L (1994). The many values of international teaching and study experiences for teacher education majors. In J. L. Easterly (Ed.), Promoting global teacher education: Seven reports (pp. 1524). Reston, VA: Association of Teacher Educators.

Major, E. M., \& Brock, C. H. (2003). Fostering positive dispositions toward diversity: Dialogical explorations of a moral dilemma. Teacher Education Quarterly, 30(4), 7-26.

Marx, H., \& Moss, D. M. (2011). Please mind the culture gap: Intercultural development during a teacher education study abroad program. Journal of Teacher Education, 62(1), 35-47.

McKay, J. W., \& Montgomery, J. (1995, April). Changes in perceptions: A comparative study of the experiential learning of international student teachers. Paper presented at the annual meeting of the American Educational Research Association, San Francisco, CA.

Merryfield, K. M. (2000). Why aren't teachers being prepared to teach for diversity, equity and global interconnectedness? A study of lived experiences in the making of multicultural and global educators. Teaching and Teacher Education, 16, 429-443. 
Wessels et al.: Meaning Perspectives in a Study Abroad Experience

Mezirow, J. (1991). Transformative dimensions of adult learning. San Francisco: Jossey-Bass.

Mezirow, J. (1996). Contemporary paradigms of learning. Adult Education Quarterly, 46(3), 158-173.

Miles, M. B., \& Huberman, A. M. (1994). An expanded sourcebook: Qualitative data analysis. Thousand Oaks, CA: Sage.

Morse, J. M., \& Richards, L. (2007). ReadMe first for a user's guide to qualitative methods (2nd ed.). Thousand Oaks, CA: Sage.

Quezada, R. L. (2004). Beyond educational tourism: Lessons learned while student teaching abroad. International Education Journal, 5(4), 458-465.

Rhodes, L. K., \& Shanklin, N. L. (1993). Windows into literacy: Assessing learners K-8. Portsmouth, NH: Heinemann.

Stachowski, L. L., Richardson, J. W., \& Henderson, M. (2003). Student teachers report on the influence of cultural values on classroom practice and community involvement: Perspectives from the Navajo reservation and from aboard. Teacher Educator, 39(1), 52-63.

Stachowski, L., \& Visconti, V. (1997). Adaptations for success: U.S. student teachers living and teaching abroad. International Education, 26, 5-20.

Strauss, A., \& Corbin, J. (1990). Basics of qualitative research: Grounded theory procedures and techniques. London: Sage.

Strauss, A., \& Corbin, J. (1998). Basics of qualitative research: Techniques and procedures for developing grounded theory (2nd ed.). Thousand Oaks, CA: Sage.

Taylor, E. W. (1997). Building upon the theoretical debate: A critical review of the empirical studies of Mezirow's transformative learning theory. Adult Education Quarterly, 48(1), 34-59.

Valencia, R. R. (1997). Conceptualizing the notion of deficit thinking. In R. R. Valencia (Ed.), The evolution of deficit thinking: Educational thought and practice (pp. 1-12). Bristol, PA: Falmer. 
Willard-Holt, C. (2001). The impact of a short-term international experience for preservice teachers. Teaching and Teacher Education, 17, 505-517.

Yang, C. C. R. (2011). Pre-service English teachers' perceptions of an overseas field experience programme. Australian Journal of Teacher Education, 36(2), 92-104. 